\title{
Mutagenesis for Oligogenic Traits with Gamma Rays and EMS in Soybean (Glycine max L.)
}

\author{
A.M. Mahalle ${ }^{1 *}$, N.J. Chikhale ${ }^{2}$, M.N. Mishra ${ }^{3}$ and S.K. Burghate ${ }^{4}$ \\ ${ }^{1}$ Gram Sevak Training Center, Amravati-444603 (MS), India \\ ${ }^{2}$ Department of Plant Breeding and Genetics, R.B.S. College, Bichpuri, Agra (UP), India \\ ${ }^{3}$ Shri Shivaji Agriculture College, Amravati-444603 (MS), India \\ ${ }^{4}$ Department of Agriculture Botany, Dr. PDKV, Akola 444104 (MS), India
}

*Corresponding author

A B S T R A C T

\begin{tabular}{|l|}
\hline K e y w o r d s \\
$\begin{array}{l}\text { JS-335, Spectrum, } \\
\text { Frequency, Gamma rays } \\
\text { and EMS }\end{array}$ \\
\hline Article Info \\
\hline $\begin{array}{l}\text { Accepted: } \\
16 \text { April } 2018 \\
\text { Available Online: } \\
10 \text { May } 2018\end{array}$ \\
\hline
\end{tabular}

\section{Introduction}

Mutation breeding has contributed to increase genetic resources and has a valuable tool for plant breeding. Genetic variations induced by mutation represent a more efficient source of genetic variability than gene pools conserved by nature (Brock, 1977). The advantage of mutation breeding is that it can be applied to altering specific characters in other wise good varieties by incorporating some useful changes such as earliness, high oil content and high yielding ability in a comparatively shorter time than the conventions breeding methods. So, the induced mutations supplement plant breeding method and confer specific improvements on a genotype without significantly altering its otherwise acceptable phenotype. Since the induction of mutation has been accepted as a useful tool in plant breeding, a systematic study of the induced mutagenesis in crop like soybean appears to be essential especially in the light of the growing need for food feed, fuel and fertilizer. Both radiations and chemical mutagens have been employed to generate the desired variability in various crop species. Though their effect on quantitative characters, investigations involving chemical mutagens are mere in soybean. Even these investigations were directed to assess the physical sensitivity 
of varieties in groundnut (Gregory, 1956; Ashri and Goldin, 1965). Intensive studies on the effect of physical and chemical mutagens and their combinations inducing viable mutations in soybean cultivars are required to derive the maximum benefits from these tools. Therefore, the present investigation was undertaken to study the effect of physical and chemical mutagens on induction of viable mutation.

\section{Materials and Methods}

Two mutagens viz., gamma rays, ethyl methane sulphonate and their combination treatments were administered. The breeder seeds of JS-335 variety of soybean were procured from Oilseed Research Unit, Dr. PDKV, Akola (MS) India and seeds of uniform size were treated with the details given in Table 1. Hundred seeds of each treatment were sowed in augmented block design with spacing of $40 \times 15 \mathrm{~cm}$. The $\mathrm{M}_{1}$ plants were harvested on single plant basis. The seeds harvested from randomly selected $50 \mathrm{M}_{1}$ plants were sown to rise $\mathrm{M}_{2}$ generation. It was expected that in each treatment should consisted 50 plants but due to lethality in some higher doses the number of plant progenies were obtained less than fifty. These all plant progenies were raised on progeny row basis along with two controls with $45 \times 15$ spacing.

The $\mathrm{M}_{2}$ generation was examined up to $15^{\text {th }}$ day after germination for chlorophyll mutation mutations. The spectrum and frequency was estimated and expressed as percentage on both $\mathrm{M}_{1}$ family and $\mathrm{M}_{2}$ plant basis. The mutant and normal seedlings were counted separately to determine the segregation ratio i.e., percentage of mutants to total progenies. The chlorophyll mutations were classified according to the system proposed by Gustafsson (1940) and Blixt (1961). The viable mutants were observed periodically from seedling stage to maturity in $\mathrm{M}_{2}$ generation and its frequency and spectrum was also estimated as like chlorophyll mutants.

\section{Results and Discussion}

\section{Chlorophyll mutations}

The spectrum of chlorophyll mutation induced by mutagenic treatment was found to vary according to the mutagen doses or concentrations. The xantha-viridis and viridis mutations were of common occurrence in most of the mutagenic treatments. The different mutagenic treatments used, differed significantly from each other for inducing chlorophyll mutations. However, combination treatments of gamma rays with ethyl methane sulphonate were found most effective in inducing chlorophyll mutations and sole treatments of ethyl methane sulphonate were found least effective. Generally all the mutagenic treatment induced maximum chlorophyll mutations namely albina, alboviridis, xantha, xantha-viridis, viridis and chlorina. Similar spectrum of chlorophyll mutations was also reported by Rajput and sarwar (1996) in lentil, Das and Kundagrami (2000) in grass pea, Geeta and Vaidyanathan (2000) in Soybean.

The mutation frequency on both $\mathrm{M}_{1}$ family basis and $\mathrm{M}_{2}$ plant basis was found maximum (26.09 percent on $\mathrm{M}_{1}$ family basis and 1.98 percent on $\mathrm{M}_{2}$ plant basis) in 300 Gy gamma rays +0.05 percent EMS. It was indicated from the results that increased doses or concentrations of the mutagens showed increased both frequency and spectrum of the chlorophyll mutations. The differential response obtained in the present investigation to various mutagenic treatments could be due to the reaction of specific genes to mutagens, which could be responding differentially to physical, chemical mutagens or their combinations. 
Table.1 Treatment details

\begin{tabular}{|c|c|}
\hline Treatment code & Treatment details \\
\hline \multicolumn{2}{|l|}{ Gamma rays } \\
\hline $\mathrm{T}_{1}-150 \mathrm{gy}$ & Irradiation of seeds with 150 Gy Gamma-rays \\
\hline $\mathrm{T}_{2}-250 \mathrm{gy}$ & Irradiation of seeds with 250 Gy Gamma-rays \\
\hline $\mathrm{T}_{3}-300 \mathrm{gy}$ & Irradiation of seeds with 300 Gy Gamma-rays \\
\hline \multicolumn{2}{|l|}{ EMS } \\
\hline $\mathrm{T}_{4}-0.05 \% \mathrm{EMS}$ & $\begin{array}{l}\text { Presoaking of seeds for } 6 \mathrm{hrs} \text {. followed by } 6 \mathrm{hr} \text {.soaking in } \\
0.05 \% \text { EMS }\end{array}$ \\
\hline $\mathrm{T}_{5}-0.1 \% \mathrm{EMS}$ & $\begin{array}{l}\text { Presoaking of seeds for } 6 \mathrm{hrs} \text {. followed by } 6 \mathrm{hr} \text {. soaking } \\
\text { in } 0.1 \% \text { EMS }\end{array}$ \\
\hline $\mathrm{T}_{6}-0.2 \% \mathrm{EMS}$ & $\begin{array}{l}\text { Presoaking of seeds for } 6 \mathrm{hrs} \text {. followed by } 6 \text { hrs. soaking } \\
\text { in } 0.2 \% \text { EMS }\end{array}$ \\
\hline \multicolumn{2}{|l|}{ Combinations } \\
\hline $\begin{array}{l}\mathrm{T}_{7}-150 \mathrm{~Gy}+0.2 \% \\
\text { EMS }\end{array}$ & $\begin{array}{l}\text { Irradiation of seeds with } 150 \mathrm{~Gy} \text {, presoaking for } 6 \text { hrs. } \\
\text { followed by } 6 \text { hrs. soaking in } 0.2 \% \text { EMS }\end{array}$ \\
\hline $\begin{array}{l}\mathrm{T}_{8}-250 \mathrm{~Gy}+0.1 \% \\
\text { EMS }\end{array}$ & $\begin{array}{l}\text { Irradiation of seeds with } 250 \mathrm{~Gy} \text {, presoaking for } 6 \mathrm{hrs} \text {. } \\
\text { followed by } 6 \mathrm{hrs} \text {. soaking in } 0.1 \% \text { EMS }\end{array}$ \\
\hline $\begin{array}{l}\mathrm{T}_{9}-300 \mathrm{~Gy}+ \\
0.05 \% \mathrm{EMS}\end{array}$ & $\begin{array}{l}\text { Irradiation of seeds with } 300 \mathrm{~Gy} \text {, presoaking for } 6 \mathrm{hrs} \text {. } \\
\text { followed by } 6 \mathrm{hr} \text {. soaking in } 0.05 \% \text { EMS }\end{array}$ \\
\hline \multicolumn{2}{|r|}{ 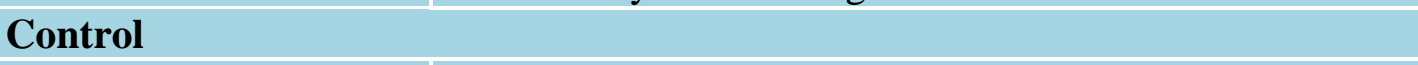 } \\
\hline $\mathrm{T}_{10}-$ Dry & Control (Dry seeds) \\
\hline $\mathrm{T}_{11}-$ Presoaked & Control (Seeds presoaked in distilled water only) \\
\hline
\end{tabular}

It is also believed that these mutations seemed to be brought about by genes located on different chromosomes. Swaminathan (1965) has suggested that the genes controlling the chlorophyll characters may be located near the centromere and proximal system is responsible for the high incidence of chlorophyll mutations data from linkage analysis in barley (Robetson, 1963 and Nilan, 1964) and maize (Neuffer, 1966) and the chromosomes aberrations studies (Natrajan and Upadhyaya, 1964) have provided evidence in support of this view. Ramanathan and Rathinam (1983) have reported high frequency of chlorophyll mutations in M2 generation by combined dose of gamma rays and EMS. The more or less similar results were also reported by Chopde (2009), Venkatachalam et al., (1999), Levy and Ashri (1975) and Shivasubramaniam (1978).

\section{Viable mutations}

The various types of viable mutations with altered plant habit were isolated in M2 generation and important ones were confirmed in M3 generation. The frequency of macro mutations expressed on M2 plant basis as well as M1 family basis was found increased as the dose of mutagens increased (Table 1). The observations recorded are in agreement with those of Vannirajan et al., (1993) in blackgram, Vandana et al., (1994) in Lentil and Nadarajan et al., (1982) in pigeonpea.

Study of spectrum of viable mutations showed that numbers of viable mutations were induced for plant type, leaf modifications, growth habit, flowering, pod characters, seed and economic mutants. The 
mutations confirmed in $\mathrm{M}_{3}$ generation. The maximum mutation rate on $\mathbf{M}_{1}$ family basis was observed in combined dose of $300 \mathrm{~Gy}$ gamma rays +0.05 percent EMS while, it was found maximum in $300 \mathrm{~Gy}$ gamma rays on $\mathrm{M}_{2}$ plant basis. It was predicted that increased mutation rate responsible for increased doses or concentrations of the mutagens. The frequency of viable mutations was recorded higher under gamma ray treatment in comparison with ethyl methane sulphonate. Gregory (1968) found 11,502 visible mutations in M2 out of 84, 213 plants following the treatment with $18.5 \mathrm{kR}$ of Xrays. Ashri and Levy (1972) found that gamma rays gave a higher mutation rate than EMS in groundnut. In present study higher mutation on M2 plant basis was obtained in combined treatment might be due to higher dose of 300 Gy gamma rays.

\section{References}

Ashri, A. and Goldin, E. 1965. The mutagenic activity of diethyl sulphate in peanuts. Radiat. Bot., 5: 431-441.

Ashri, A. and Levy, A. 1972. Mutation yield and types obtained in peanuts (Arachis hypogaea L.) by treating mature seeds with EMS and gamma rays and developing embryos with EMS. Mutations in Plant Breeding, IAEA, Vienna, pp. 1-12.

Blixt, S. 1961. Quantitative studies of induced mutations in Peas, Chlorophyll Mutations Agric. Hort. Gen., 18:216227.

Brock, R.D. 1977. Prospectus and perspectives in mutation breeding.177232. In: Genetic Diversity in Plants, Ed. Muhammed, A.R., Akseland VonBorste R., Pennum Press, New York.

Chopde, V.L. (2009) Mutation breeding in groundnut. M.Sc. (Agri.) Thesis, Junagadh Agriculture University, Gujarat, India.
Das, P.K. and S. Kundagrami (2000): Frequency and spectrum of chlorophyll mutations in grass pea induced by gamma-rays. Indian J. Genet. 60(2): 239-241.

Geetha, K. and P. Vaidyanathan (2000): Studies on induction of chlorophyll mutations in soybean (Glycine max L.) through physical and chemical mutagen. Agril. Sci. Digest. 20(1): 33 - 35.

Gregory, W.C. 1956. Induction of useful mutations in the peanut. Brookhaven Symp. Biol., 9: 177-190.

Gregory, W.C., 1968. A radiation breeding experiment with peanuts. Radiat. Bot., 8: 81- 147.

Gustafsson, A. (1940). The mutation systems of chlorophyll apparatus. Lands Univ. Arsska N.R. Acad. 236: 1 - 40.

Levy, A. and Ashri, A. (1975). Ethidium bromide - an efficient mutagen in higher plants. Mutation Res., 28: 397-404.

Nadarajan, N., R.R. Sethupathi and N. Sivasamy (1982). Investigation on induced macromutants in Cajanus cajan (L.) Millsp. Madras Agric. J. 69 (1): 713-717.

Natrajan, A.T. and Upadhya, M.D. (1964). Localizes chromosomes breakage induced by EMS and HI in Vicia feba., Chromosoma, 15: 156-169.

Neuffer, M.G. (1966) Linkage maps of maize chromosomes. Maize Genet. Coop. Newsletter, 40: 167-172.

Nilan, R.A. (1964). The genetics and cytology of barley. Washington State Univ. Press. Pullman. Wash, pp: 278.

Rajput, M.A. and G. Sarwar (1996). Radiation induced chlorophyll mutations in lentil. Lens. Newsl. 23(1/2): 3 - 4.

Ramanathan, T. and Rathinam, M. (1983) Effect of mutagenic treatments on character association in groundnut (Arachis hypogaea L.) Madras Agric. J., 70 (7): 421-246. 
Robertson, D.W. (1963) New genes in barley with their related to linkage groups and chromosomes. Proc. $1^{\text {st }}$ International Barley Genet, Wageningen, Netherland, pp. 150-167.

Shivasubramaniam, S. (1978) Studied on induce mutations in peanut, (Arachis hypogaea L.). Ph.D. (Agri.) Thesis, Tamilnadu Agricultural University, Coimbatore, India.

Swaminathan, M.S. (1965) A comparison of mutation production in diploids and Polyploids. Radiat. Bot., 5: 619-641.

Vandana; A. Tripathi and O.K. Dubey (1994): Frequency and spectrum of mutations induced by ethylmethane sulfonate (EMS) and diethyl sulpfate (DBS) in lentil var. K-85. 21(1): 16 - 19.

Vannirajan, C., P. Vivekanandan and J. Ramlingam (1993): Spectrum and frequency of chlorophyll and viable mutations in M2 generation of blackgram. Crop Improv. 20 (2): 215 218.

Venkatachalam, P., Geetha, N. and Jayabalan, N. (1999) Frequency and spectrum of chlorophyll mutations in groundnut (Arachis hypogaea L.), Bangladesh J. Bot., 28 (1): 17-25.

\section{How to cite this article:}

Mahalle, A.M., N.J. Chikhale, M.N. Mishra and Burghate, S.K. 2018. Mutagenesis for Oligogenic Traits with Gamma Rays and EMS in Soybean (Glycine max L.). Int.J.Curr.Microbiol.App.Sci. 7(05): 1781-1785. doi: https://doi.org/10.20546/ijcmas.2018.705.208 